\title{
PENGUMUMAN DIVIDEN REGULER TERHADAP FUTURE UNEXPECTED EARNINGS: SUATU PENELITIAN EMPIRIS DI BURSA EFEK JAKARTA
}

\author{
Dedi Herdiansyah \\ Januardi M. Diah \\ Arianto \\ Tashadi Tarmizi \\ Politeknik Negeri Pontianak
}

\begin{abstract}
Abstrak
Hasil-hasil penelitian terdahulu tentang apakah dividen mengandung informasi yang berguna bagi pasar masih saling bertentangan. Hasil penelitian Natts (1973, 1976), Ang (1975) dan Gonedes (1978) tidak menemukan bukti bahwa pengumuman dividen mengandung informasi. Sedangkan hasil penelitian terbaru yang dilakukan Laub (1976), Charest (1978), Aharony dan Swary (1980), Woolridge (1982), Asquith dan Mullins (1988), Venkantesh dan Chiang (1986). Healy dan Seifert (1992), dan Mande (1994) mendukung bahwa pengumuman dividen mengandung informasi

Penelitian ini merupakan replikasi dari dari model penelitian yang dilakukan oleh Aharony dan Dotan (1994). Penelitian ini mencoba untuk mempertegas konfirmasi dari observasi-observasi yang mengungkapkan bahwa peningkatan (penurunan) harga saham. Populasi penelitian ini adalah seluruh perusahaan yang terdaftar di Bursa Efek Jakarta (BEJ) dengan periode pengumuman dividen tahun 1992 - 1995. Pemilihan periode tersebut dilakukan sebelum Indonesia mengalami krisis untuk menghindari bias karena selama krisis banyak saham yang menjadi kurang atraktif

Hasil penelitian ini menunjukkan bahwa pengumuman perubahan dividen tidak berpengaruh secra signifikan terhadap peningkatan (penurunan) keuntungan perusahaan. Hasil penelitian juga memberikan indikasi bahwa pengumuman dividen tidak memiliki kandungan informasi ke pasar. Peningkatan (penurunan) dividen lebih disebabkan keuntungan perusahaan pada periode yang sama dengan dilakukannya pengumuman dividen. $\mathrm{Hal}$ ini mengindikasikan bahwa peningkatan (penurunan) dividen tidak menggambarkan peluang profitable perusahaan di waktu yang akan datang.
\end{abstract}

Kata kunci: unexpected dividen change, future unexpected earnings, and information content of dividend.

\section{LATAR BELAKANG PENELITIAN}

Manajemen mempunyai dua alternatif perlakuan terhadap penghasilan bersih sesudah pajak (EAT) perusahaan: 1) dibagi kepada para pemegang saham dalam bentuk dividen, dan 2) diinvestasikan kembali ke perusahaan sebagai laba ditahan (retained earnings). Pada umumnya EAT (Earnings After Tax) dibagi dalam bentuk dividen dan sebagian lagi di investasikan kembali. Artinya, manajemen harus membuat 
keputusan tentang besarnya EAT yang dibagikan sebagai dividen. Keputusan tentang dividen ini disebut sebagai kebijakan dividen (dividend policy).

Hipotesis "informational content of dividends" (Miller-Modigliani) mengatakan bahwa pengumuman cash dividend merefleksikan perubahan penilaian manajemen terhadap keuntungan perusahaan di waktu yang akan datang. Hipotesis ini didukung oleh sejumlah teori dan penelitian empirik terpercaya. Suatu pendekatan teoritikal yang terpenting adalah "signaling theory" yang dikembangkan oleh Spence, seperti yang duikutip oleh Aharony dan Dotan (1994), dimana model berasumsi bahwa dividen mengandung pertanda (signal). Model ini mengatakan bahwa, karena dividen menyediakan signal, bentuknya adalah kemungkinan profit perusahaan di waktu yang akan datang. John dan William (1985), Miller dan Rock (1985) juga mengembangkan dividend signaling theory. Model yang dikembangkan oleh empat peneliti tersebut memberikan penegasan yang serupa dengan Bhattaracharya (1979) bahwa dividen merupakan isyarat yang digunakan oleh manajer untuk menunjukkan kemampuan perusahaan.

Pada prakteknya perusahaan cenderung memberikan dividen dengan jumlah yang relatif stabil atau meningkat secara teratur. Kebijakan ini kemungkinan besar disebabkan oleh asumsi bahwa (Atmaja, 1999: 1) investor melihat kenaikkan dividen sebagai suatu pertanda baik bahwa perusahaan memiliki prospek cerah, demikian sebaliknya, dan 2) investor cenderung lebih menyukai dividen yang tidak berfluktuasi tapi dividen yang stabil.

Pengumuman dividen dianggap memiliki kandungan informasi apabila pasar bereaksi pada saat pengumuman tersebut diterima oleh pasar. Reaksi terhadap pengumuman ini dapat ditunjukkan dengan adanya perubahan harga dan atau volume perdagangan sekuritas dari perusahaan yang bersangkutan. Untuk mengukur reaksi dalam bentuk perubahan harga dapat menggunakan return sebagai nilai perubahan harga atau dengan menggunakan abnormal return (Jogiyanto, 1998). Jika menggunakan abnormal return, maka dapat dikatakan bahwa suatu pengumuman yang memiliki kandung informasi akan memberikan abnormal return, sebaliknya jika tidak mengandung informasi, maka tidak akan memberikan abnormal return.

Penelitian ini merupakan replikasi dari model penelitian yang dilakukan oleh Aharony dan Dotan (1994). Model ini berusaha mengembangkan instrumen pengukuran terhadap hipotesis "informational content of dividends". Kebutuhan untuk melakukan penelitian ini didasarkan pada penelitianpenelitian yang sudah ada sebelumnya, dimana hasil-hasil studi tentang apakah dividen mengandung informasi yang berguna untuk pasar juga menghasilkan kesimpulan yang masih tercampur (Jogiyanto, 1998). Watts (1973, 1976), Ang (1975) dan Gonedes (1978) tidak menemukan bukti bahwa dividen mengandung informasi. Akan tetapi, hasil dari studi-studi terbaru mendukung bahwa dividen mengandung informasi. Hasil-hasil 
penelitian yang menemukan bukti kandungan informasi dari pengumuman dividen misalnya adalah Laub (1976), Charest (1978), Aharony dan Swary (1980), Woolridge (1982), Asquith dan Mullins (1983), Venkantesh dan Chiang (1986), Healy dan Palepu (1988), Chang dan Chen (1991), Eddy dan Seifert 1992), serta Mande (1994). Beberapa pendekatan telah digunakan untuk menguji kandungan informasi dari dividen. Diantaranya pendekatan yang dilakukan dengan mengamati pergerakan harga sekuritas sekitar pengumuman perubahan dividen yang tidak terekspektasi (unexpected dividend changes), dikutip dari Jogiyanto (1998).

Penelitian ini mencoba untuk mempertegas konfirmasi dari observasi-observasi yang mengungkap bahwa peningkatan (penurunan) dividen secara signifikan akan diikuti oleh peningkatan (penurunan) harga saham. Alasan mengapa diperlukannya penelitian lebih lanjut, karena semakin banyak bukti, akan lebih mempertegas dan memperkuat validitas mengenai hipotesis "informational content of dividend", Aharony dan Dotan (1994).

\section{PERUMUSAN MASALAH}

Permasalahan pertama yang akan peneliti ajukan menyangkut latar belakang di atas adalah:

- Apakah pengumuman dividen dari perusahaan-perusahaan yang terdaftar di Bursa Efek Jakarta, berpengaruh positif (negatif) terhadap peningkatan (penurunan) future earnings?

Sedangkan permasalahan kedua yang juga merupakan permasalahan utama penelitian empirik ini adalah suatu upaya untuk menguji kandungan informasi dari pengumuman cash dividen, jika dividen memiliki kandungan informasi maka merupakan sinyal bagi investor bahwa pengumuman dividen merefleksikan perubahan penilaian manajemen terhadap keuntungan perusahaan di waktu yang akan datang. Untuk itu masalah kedua yang akan diteliti adalah:

- Apakah pengumuman dividen dari perusahaan-perusahaan yang terdaftar di Bursa Efek Jakarta, memiliki kandungan informasi sehingga akan berpengaruh pada earnings periode berikutnya, sesuai dengan hipotesis "informational content of dividend"?

Pengujian kandungan informasi hanya menguji reaksi dari pasar, tetapi tidak menguji seberapa cepat pasar itu berreaksi. Jika pengujian melibatkan kecepatan reaksi dari pasar untuk menyerap informasi pengumuman dividen, maka pengujian ini merupakan pengujian efisiensi pasar bentuk setengah kuat. Dengan demikian pengujian efisiensi pasar bentuk setengah kuat seharusnya dilakukan setelah pengujian kandungan informasi. Jadi dua pengujian di atas bisa dikatakan sebagai 2 bentuk pengujian yang berbeda (Jogiyanto, 1998). 


\section{TUJUAN PENELITIAN}

Tujuan penelitian ini adalah sebagai berikut:

- Untuk melihat apakah ada pengaruh positif (negatif) terhadap EPS dari pengumuman dividen yang meningkat (menurun) di BEJ.

- Untuk memperoleh bukti empiris dengan menggunakan model Aharony dan Dotan (1994), mengenai kandungan informasi (information content) dari perubahan dividen terhadap earnings perusahaan pada periode setelah periode perubahan dividen terjadi.

\section{MANFAAT PENELITIAN}

- Memberikan informasi dan bukti empiris mengenai ada tidaknya kandungan informasi dari perubahan dividen terhadap prospek keuntungan perusahaan di waktu yang akan datang.

- Bagi perusahaan, hasil dari penelitian ini bisa dijadikan pedoman dalam menyusun kebijakan dividen (dividend policy). Jika hasil dari penelitian ini signifikan, maka berarti perusahaan paling tidak harus menjaga kestabilan pembayaran dividennya.

\section{TINJAUAN LITERATUR DAN PENGEMBANGAN HIPOTESIS}

Miller dan Modigliani memperkenalkan ide bahwa dividen menghasilkan informasi tentang profitabilitas perusahaan lewat perubahan harga saham. Mereka menyatakan bahwa investor kemungkinan menginterpretasikan perubahan dividen sebagai perubahan pandangan manajemen terhadap prospek keuntungan perusahaan di masa yang akan datang (Wansley dkk, 1991).

Watts (1976), pada upaya awalnya dalam mengidentifikasi hubungan tersebut memperoleh kesimpulan bahwa observasi mengenai unexpected dividend change tidak bisa disimpulkan sebagai tanda bahwa perubahan future unexpected earnings, karenanya akan sangat berbeda dari nol. Brickley (1983), menguji return saham serta pola dividen dan earnings di seputar tanggal pengumuman dividen, dengan membandingkannya dengan apa yang terjadi di seputar tanggal pengumuman peningkatan dividen. Dengan memperhatikan pola earnings, Brickley menemukan bahwa peningkatan dividend annual reguler pada peringkat 35 terbesar, akan menghasilkan peningkatan earnings sebesar 30\% pada tahun berikutnya. Namun tidak ada kontrol yang dilakukan terhadap informasi potensial yang terkandung dalam pengumuman past dan current earnings. Oleh karena itulah, tidak mungkin untuk menarik kesimpulan apakah peningkatan earnings 
yang diobservasi pada periode berikutnya sebagai akibat dari peningkatan dividen yang lebih besar dari apa yang diharapkan berdasarkan past earnings saja.

Menggunakan metode yang berbeda, Healy dan Palepu (1988) menggunakan sample perusahaan yang melakukan inisiasi dan omisi terhadap dividennya. Mereka menemukan bahwa perusahaan yang melakukan inisiasi (omisi) mengalami peningkatan (penurunan) yang signifikan, dalam annual earnings-nya paling tidak satu tahun sebelum perubahan dividen, pada tahun yang bersamaan, dan satu tahun setelah perubahan dividen.

Denis dan Sarin (1994) berpendapat penjelasan tentang hubungan positif antara pengumuman dividen dan perubahan harga saham. Pertama, adanya teori dividend signaling dimana perubahan dividen mengandung informasi tentang aliran kas yaitu peningkatan (penurunan) dividen mengandung good (bad) news tentang aliran kas perusahaan pada saat ini atau di waktu yang akan datang. Kedua, perubahan dividen dapat memberikan informasi mengenai investasi perusahaan di waktu yang akan datang (Lang dan Lintzenberger, 1989).

Berdasarkan uraian di atas, maka peneliti mengajukan hipotesishipotesis sebagai berikut:

$\boldsymbol{H}_{1 \mathrm{a}}$ : Terdapat hubungan yang positif antara peningkatan unexpected dividend terhadap peningkatan future unexpected earnings.

$$
H_{1 a}: e[\mathrm{UEY} j(i) / \Delta \mathrm{D}>0]>0
$$

$\boldsymbol{H}_{1 b}$ : Terdapat hubungan yang positif antara penurunan unexpected dividend terhadap penurunan future unexpected earnings.

$$
H_{1 b}: \text { e }[\mathrm{UEYj}(i) / \Delta \mathrm{D}<0]<0
$$

Mengenai studi empiris yang membahas masalah kandungan informasi dari pengumuman dividen ada beberapa penelitian yang telah dilakukan. Watts (1973) yang melakukan penelitian mengenai kandungan informasi dividen menguji hubungan antara unexpected dividend change dan future profit, serta abnormal return perusahaan-perusahaan yang mengumumkan unexpected dividend change (perubahan dividen yang tak terduga). Watts memperoleh bukti bahwa unexpected dividend change tersebut hanya memberikan sedikit bukti informasi mengenai laba perusahaan di waktu yang akan datang dan tidak terdapat abnormal return dalam bulan-bulan di sekitar pengumuman dividen.

Asquith dan Mullins (1986) mengemukakan beberapa alasan mengapa manajer dan investor lebih berreaksi pada informasi yang dibawa oleh pengumuman dividen dibandingkan informasi yang terkandung dari pengumuman laba. Hal ini disebabkan oleh anggapan bahwa dalam laporan laba terdapat unsur manipulasi dan tidak memberikan gambaran mengenai kondisi perusahaan di waktu yang akan datang. Meskipun demikian, terdapat juga bukti bahwa pengumuman laba berdampak pada 
reaksi harga saham. Dengan demikian bahwa pengumuman laba juga dapat dikatakan memiliki kandungan informasi meskipun hanya merupakan shorterm information content.

Di Indonesia, penelitian-penelitian serupa juga sudah ada yang pernah melakukan. Amsary (1993) menguji apakah informasi mengenai perubahan dividen mempunyai arti bagi investor di Bursa Efek Jakarta. Dalam menaksir abnormal return, diasumsikan bahwa return saham individu dipengaruhi oleh return secara keseluruhan. Hasil penelitian mengindikasikan bahwa pengumuman dividen merupakan sinyal bagi investor dalam pengambilan keputusan mengenai dividen.

Sudjoko (1999) menemukan adanya kandungan informasi. Riset yang dilakukan berdasarkan dividend signaling theory dengan mempertimbangkan dividen yang meningkat saja, dengan asumsi adanya kesempatan investasi. Pengujian kandungan informasi didasarkan atas pengumuman dividen yang meningkat secara konsisten dan tidak konsisten. Hasil riset yang dilakukan Sudjoko mengindikasikan bukti mengenai adanya kandungan informasi dari dividen, tetapi belum secara jelas menunjukkan apakah reaksi pasar yang terjadi disebabkan oleh pengumuman dividen saja atau ada faktor lain misalnya pengumuman laba dalam periode yang bersamaan dengan pengumuman dividen tersebut.

Dalam penelitian kali ini, pengumuman laba juga diantisipasi dengan cara memasukkan unexpected earnings yield (UEY) pada periode yang sama ketika pengumuman dividen dilakukan dan dimasukkan ke dalam regresi. Hal ini dilakukan dengan maksud untuk menghindari bias bahwa bahwa perubahan peningkatan (penurunan) dividen bukan disebabkan karena pengumuman laba pada tahun bersamaan, tetapi merupakan kandungan informasi mengenai keuntungan (kerugian) bagi perusahaan di waktu yang akan datang ( future earnings).

Berdasarkan hal di atas, maka hipotesis kedua penelitian adalah:

$\boldsymbol{H}_{2}$ : Perubahan dividen mengandung informasi mengenai future earnings, atau pengumuman dividen mengandung informasi terhadap keuntungan perusahaan di waktu yang akan datang.

$$
H_{2}: a_{0 \neq} a_{1 \neq} a_{2 \neq} a_{3 \neq} a_{4 \neq} a_{5 \neq} 0
$$

\section{METODE PENELITIAN}

\section{Popupasi dan Sampel}

Populasi dari penelitian ini adalah seluruh perusahaan yang terdaftar di Bursa Efek Jakarta (BEJ), yaitu dari Indonesia Capital Market Directory. Data yang dibutuhkan diantaranya terdiri dari: harga saham, Earnings Per Share (EPS), serta pengumuman deviden tahun 1992, 1993, 1994, 1995, dan 1996. Pemilihan periode tersebut dilakukan sebelum 
Indonesia mengalami krisis untuk menghindari bias, karena selama krisis banyak saham yang menjadi kurang atraktif. Metode pengumpulan sampel menggunakan purpose sampling.

Kriteria pengambilan sampel yang digunakan adalah sebagai berikut:

- Sampel adalah semua perusahaan yang terdaftar di Bursa Efek Jakarta, kecuali perusahaan-perusahaan dalam bidang keuangan (financial service), salah satu alasan kalau melibatkan semua perusahaan jumlahnya akan sangat besar.

- Perusahaan memiliki kebijakan deviden, sehingga dapat dijadikan indikasi bahwa setiap perubahan deviden merupakan perubahan harapan manajemen.

- Sampel hanya melibatkan perusahaan dividen yang tidak terkombinasi dengan distribusi abnormal lainnya (other abnormal distribution), dalam hal ini yang dimaksud yaitu stock split dan stock dividend (Aharony \& Dotan, 1994).

\section{Analisa Data}

Unexpected earning dan dividend didefinisikan sebagai perbedaan antara nilai yang sebenarnya terjadi (actual) dan nilai harapan (expected). Model yang digunakan untuk annual earnings adalah random-walk with drift, yang didefinisikan:

$$
e\left(A_{t+1}\right)=A_{t}+w,
$$

dimana:

$$
A_{t}=\text { jumlah EPS pertahun perusahaan }
$$

$w$ = penyimpangan (a drift term), yang dihitung sebagai rata-rata dari perbedaan seri annual earning.

Model yang digunakan ini mampu untuk melihat perilaku time-series annual earnings (Albrecht, et. Al., 1977), seperti yang dikutip Aharony dan Dotan (1994), parameter $w$ dalam persamaan (1) diestimasi dari setiap perusahaan, menggunakan earnings pertahun dimana ekspektasi earnings akan diuji.

Perlu dicatat, bahwa penolakan hipotesis $H_{0}$ tidak menjamin bahwa perubahan dividen menyediakan informasi mengenai earnings di waktu yang kan datang. Kemungkinan perubahan dividen merupakan reaksi dari perubahan earnings pada tahun yang bersamaan. Akibat kekurangan dari model ekspektasi earnings ini, untuk mengontrol kemungkinan tersebut perlu digunakan tes kedua, cross sectional multiple OLS regressions dalam bentuk sebagai berikut:

$$
\text { UEY }_{J(t+1)}=a_{0}+a_{1} . \Delta D_{J}+a_{2} . U E Y_{J}(0)+\bar{e}_{J}
$$

dimana:

UEY ${ }_{J}(0)=$ unexpected earnings yield dari perusahaan $j$ pada tahun perubahan dividen terjadi (event annual)

$\bar{e}_{j} \quad=$ a random error, pada tahun setelah event annual. 
Jika perubahan dividen tidak mengandung informasi mengenai earnings di waktu yang akan datang dan bertahan pada earnings sekarang, maka koofisien $\Delta \mathrm{D}$ akan sama dengan 0 untuk tiap tahun, atau dibawah hipotesis nol $\left(H_{0}\right)$, sementara jika terjadi sebaliknya maka berada pada hipotesis alternatif. Kemudian, UEY ${ }_{j k}(t+1)$ didefinisikan sebagai unexpected earnings yield dari perusahaan $j$ dalam tahun setelah event annual. Harga penutupan saham perusahaan ke-j dalam tahun t-1 digunakan untuk menstandarisasi error forecast tahunan (Aharony \& Dotan, 1994).

Beberapa studi (seperti, Aharony dan Swary, 1980; Bar Yosef dan Sarig, 1992), seperti yang dikutip Aharony dan Dotan (1994), menunjukkan perbedaan reaksi investor terhadap kenaikan dan penurunan deviden. Adalah mungkin bagi manajer untuk me-resetting kebijaksanaan dividennya, bereaksi secara berbeda terhadap harapan kenaikan EPS dibanding harapan penurunan EPS. Untuk menghadapi kemungkinan ini, slope variabel $(\Delta \mathrm{D})$ pada persamaan (2) diganti dengan $\Delta \mathrm{D}^{+}{ }_{\mathrm{J}}$ untuk perubahan dividen yang positif, dan $\Delta \mathrm{D}^{-}$, untuk perubahan dividen yang negatif. Untuk kasus dividen yang tidak mengalami perubahan, kedua variabel ini diset menjadi 0 (zero). Variabel lain yang digunakan untuk membedakan, dilakukan pemisahan intercept. Maka, $D_{1}$ dan $D_{N}$ dimasukkan sebagai dummy variable :

$$
\begin{aligned}
\text { Untuk } \mathrm{D}_{\text {l }} ; & 1 \text { jika } \Delta \mathrm{D}_{\mathrm{J}}>0 \\
& 0 \text { jika lainnya }
\end{aligned} \quad \text { dan } \quad \mathrm{D}_{N_{\mathrm{J}}} ; \begin{aligned}
& 1 \text { jika } \Delta \mathrm{D}_{\mathrm{J}}=0 \\
& \text { 0 jika lainnya }
\end{aligned}
$$

Persamaan regresi (2) sekarang menjadi persamaan regresi 2a):

$\operatorname{UEY}_{J(t+1)}=a_{0}+a_{1} . \Delta D^{+}{ }_{J}+a_{2} . \Delta D_{J}+a_{3 .} U E Y_{J}(0)+a_{4 .} D_{1 J}+a_{5 .} D_{N J}+\bar{e}_{J}(2 a)$

\section{Pengukuran Variabel} sebagai berikut:

Pengukuran Variabel yang digunakan dalam penelitian adalah dimana :

$$
\operatorname{UEY}_{J(t+1)}=a_{0}+a_{1} \cdot \Delta D_{J}+a_{2} \cdot U E Y_{J}(0)+\bar{e}
$$

$\Delta \mathbf{D}=$ persentase perubahan unexpected dividend pertahun, dihitung sebagai perbedaan antara dividen aktual (D) dan nilai ekspektasinya (Ď), dibagi dengan nilai ekspektasinya. [ $\triangle \mathrm{D}=$ (D - D $) / \mathrm{D})]$.

$\mathrm{UEY}_{s t}=$ perbedaan antara EPS aktual dan EPS ekpektasi dibagi harga saham penutupan dari perusahaan $j$ pada tahun $t-1$.

$$
\operatorname{UEY}_{J(t+1)}=a_{0}+a_{1} . \Delta D^{+}{ }_{J}+a_{2} . \Delta D^{-}{ }_{J}+a_{3} . U E Y_{J}(0)+a_{4} \cdot D_{1 J}+a_{5} \cdot D_{N J}+\bar{e}_{J}
$$
dimana:

$\Delta \mathrm{D}^{+}{ }_{\mathrm{J}}=$ perubahan dividen yang positif,

$\Delta \mathbf{D}_{{ }_{j}}=$ perubahan dividen yang negatif.

Untuk kasus dividen yang tidak mengalami perubahan, kedua variabel ini diset menjadi 0 (zero). Untuk $\mathbf{D}_{l}$, dan $\mathbf{D}_{\mathrm{N}}$ yang dimasukkan sebagai dummy variables penjelas dalam persamaan (2), dimana: 
Untuk $D_{I_{\jmath}} ; 1$ jika $\Delta D_{\jmath}>0$ dan $\quad D_{\mathrm{N}_{\jmath}} ; 1$ jika $\Delta D_{\jmath}=0$

0 jika lainnya 0 jika lainnya

\section{Pengujian Hipotesa}

Pengujian hipotesa pertama

sebagai berikut:

Untuk menguji hipotesis $\mathrm{H}_{l a}$ dan $\mathrm{H}_{l b}$, maka rata-rata UEY dihitung

$$
\overline{U E Y}=\frac{1}{N_{1}} \sum_{j} \sum_{k} U E Y_{j k}(i), \text { untuk } \Delta \mathrm{D}>0 \text { dan } \Delta \mathrm{D}<0
$$

dan

$$
\overline{\mathrm{UEY}}=\frac{1}{\mathrm{M}_{\mathrm{i}}} \sum_{\mathrm{j}} \sum_{\mathrm{k}} \mathrm{UEY}_{\mathrm{jk}}(\mathrm{i}), \text { untuk } \Delta \mathrm{D}=0
$$

dimana $N_{i}$ adalah jumlah observasi dari sampel dividen yang berubah, sedangkan $\mathrm{M}_{i}$ adalah jumlah observasi dimana dividen tidak berubah. Untuk menguji signifikansi secara statistik dari UEY, pertama uji t (t-test):

$$
\overline{\mathrm{t}} \overline{(U E Y)}(\mathrm{i})=\frac{U E Y(i) \cdot \sqrt{N i}}{\operatorname{SD}\left[U E Y_{j k}(i)\right]}
$$

dimana:

$$
\operatorname{SD}[\operatorname{UEY} j k(i)]=\sqrt{ } \frac{1}{(N i-1)} \sum_{j} \sum_{k}\left[U E Y_{j k}(i)-U E Y(i)\right]^{2}
$$

Langkah pengujian kedua untuk hipotesa adalah dengan melakukan uji normalitas data. Uji distribusi normal ini sangat penting, karena jika ternyata data tersebut jauh dari asumsi sebuah distribusi normal, maka pada kelompok data tersebut tidak dapat dilakukan secara uji hipotetis statistik parametrik, namun akan dilakukan pengujian dengan statistik non parametrik tersebut. Dalam penelitian ini, uji normalitas data didasarkan pada nilai skewness seperti yang telah diberikan dalam buku SPSS (1998) yang berupa rule of thumb, yaitu -2 sampai dengan +2 . Formulanya sebagai berikut:

$$
Z=\frac{\text { Skewness }}{\text { S.e.skewness }}
$$

Asumsi normalitas dapat ditolak, jika nilai z kurang dari atau melebihi nilai kritis. Apabila ternyata data tidak berdistribusi normal, maka SPSS mengusulkan menggunakan teohos non parametrik seperti Mann Whitney-Wilcoxon Signed Rank Test untuk data 2 sampel bebas atau uji Kruskal-Wallis untuk $\mathrm{K}$ sampel bebas. 


\section{Pengujian hipotesa kedua $\left(\mathrm{H}_{2}\right)$}

Untuk menguji hipotesis $\mathrm{H}_{2}$, estimasi dilakukan dengan memasukkan data dividen yang berubah (change case) maupun yang tidak berubah (noshange cash). Hipotesis nol diterima, ketika $a_{0}=a_{1}=a_{2}=a_{4}=a_{5}=0$, untuk A. Untuk $a_{3}$, jika model ekspektasi earnings yang digunakan untuk mengestimasi UEY, (i) tidak secara penuh terpengaruh terhadap current unexpected earnings akan berbeda dari nol $\left(a_{3} \neq 0\right)$, dan cenderung positif, akibat serial korelasi yang positif dari Unexpected earnings (Bernard and Thomas, 1990). Akhirnya, jika $a_{0} \neq a_{1} \neq a_{2} \neq a_{3} \neq a_{4} \neq a_{5} \neq 0$, maka hipotesis null ditolak (Aharony \& Dotan, 1994).

Kemudian untuk tujuan menguji hubungan antara perubahan deviden dengan unexpected earnings yield, maka koofisien $a_{0} a_{4}$ dan $a_{5}$ harus diinterpretasikan sebagai berikut (Aharony \& Dotan, 1994) : $a_{0}$ mewakili intersep bagi grup dividen yang menurun; $\left(a_{0}+a_{4}\right)$ mewakili intersep bagi grup dividen yang meningkat; dan $\left(a_{0}+a_{5}\right)$ mewakili intersep bagi grup dividen yang tetap, dan dilakukan uji $F$.

\section{ANALISA DATA}

\section{Analisa Data \\ Pengujian hipotesis pertama $\left(\boldsymbol{H}_{l a}\right.$ dan $\left.\boldsymbol{H}_{l b}\right)$}

Pengujian untuk hipotesis pertama ini ada beberapa langkah yang harus dilakukan. Rumus untuk mencari nilai rata-rata unexpected earning yield, standar deviasi, dan nilai t hitungnya telah disajikan sebelumnya. Berikut adalah rangkuman hasil perhitungan yang disajikan dalam bentuk tabel 1.

Tabel 1.

Rata-Rata Unexpected Earning Yield Dividen Berubah dan Tidak Berubah

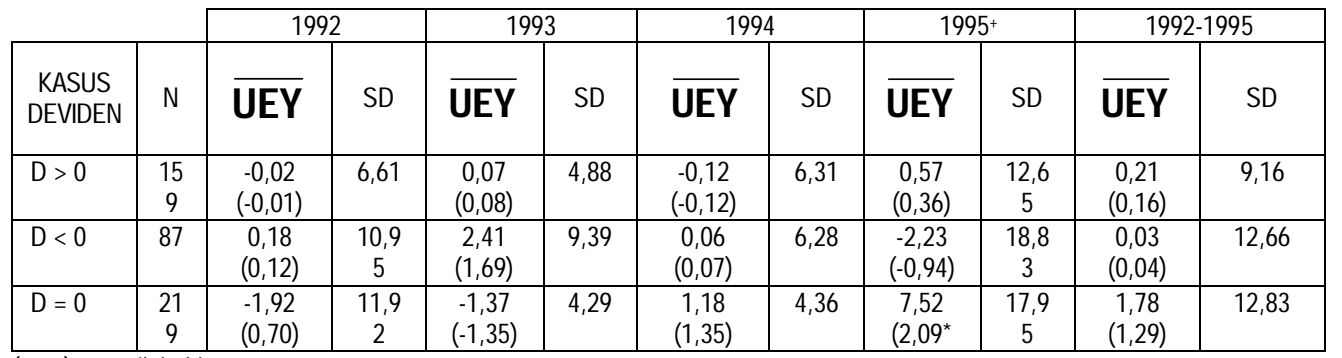

$(\ldots)=$ nilai t hitung

= jumlah kasus

${ }^{* *}(++)$ signifikan pada level $1 \%$ uji $\mathrm{t} 2$ sisi (uji Kruskal Wallis 2 arah)

${ }^{*}(+)$ signifikan pada level $5 \%$ uji 2 sisi (uji Kruskal Wallis 2 arah) 
Table 1. menunjukkan rata-rata persentase unexpected earning yield ( $\overline{\mathbf{U E Y}}$ (i)) yang terjadi setelah pengumuman unexpected dividen yang meningkat, menurun, maupun tetap. Hasil-hasil penelitian disajikan pertahun (1992, 1993, 1994, dan 1995) untuk melihat apakah hasil penelitian yang diperoleh mengindikasikan time-period specific atau berkaitan dengan tahun tertentu (Aharony \& Dotan, 1994). Selain itu hasil juga disajikan secara keseluruhan dalam periode 1992-1995.

Hasil penelitian mengindikasikan, secara keseluruhan (entireperiod) untuk dividen yang meningkat $(\Delta D>0)$, menurun $(\Delta D<0)$, maupun dividen tetap $(\Delta \mathrm{D}=0)$ persentase $\overline{U E Y}$ menunjukkan hasil yang tidak signifikan secara statistik, baik menggunakan uji t (t-test), maupun test non parametrik Kruskal Wallis. Kecuali pada periode tahun 1995 tes non parametriknya menghasilkan signikansi pada level 5\% (dengan Asymptot sign, sebesar 0,017). Namun kesimpulan yang akan peneliti ambil adalah tetap berdasarkan fenomena hasil olah data secara keseluruhan dimana untuk periode 1992-1995 (overall), berdasarkan tabel 2 nilai t hitung yang signifikan hanya berada pada grup $\Delta \mathrm{D}=0$ pada tahun 1995 (t-hitung sebesar 2,09, signifikan pada level $5 \%$ ) dengan hasil tes non parametrik periode 1995, Asymptot sign, sebesar 0,017. Sedangkan yang lainnya semua tidak signifikan. Hasil ini memberikan indikasi bukti pertama bahwa kenaikan (penurunan) dividen tidak memberikan isyarat terhadap peningkatan (penurunan) laba yang akan diperoleh perusahaan pada waktu yang akan datang (future earnings), sehingga hipotesis nol $\left(\mathrm{H}_{0}\right)$ tidak dapat ditolak.

Tabel. 2

Rata-rata Persentase Unexpected Earning Yield Untuk Masing-masing Kasus Dividen

\begin{tabular}{|l|c|c|c|c|c|c|}
\hline KASUS DIVIDEN & $\mathrm{N}$ & 1992 & 1993 & 1994 & 1995 & $1992-1995$ \\
\hline Dividen inisiasi & 8 & - & - & - & - & $\begin{array}{c}8,66 \\
(0,8)\end{array}$ \\
\hline Dividen meningkat & 150 & 0,63 & 0,15 & 0,13 & $-0,01$ & $-0,24$ \\
& & $(0,49)$ & $(0,17)$ & $(0,13)$ & $(-1,08)$ & $(0,46)$ \\
\hline Dividen omisi & 16 & - & - & - & - & 3,02 \\
& & & & & & $(0,52)$ \\
\hline Dividen menurun & 203 & 0,18 & 0,69 & 0,25 & $-1,94$ & $-0,21$ \\
& & $(0,12)$ & $(1,02)$ & $(0,29)$ & $(-0,74)$ & $(-0,26)$ \\
\hline
\end{tabular}

$(\ldots)=$ nilai t hitung

$\mathrm{N} \quad=$ jumlah kasus

${ }^{* *}(++)$ signifikan pada level $1 \%$ uji t 2 sisi (uji Mann Whitney-Wilcoxon 2 arah)

${ }^{*}(+)$ signifikan pada level 5\% uji t 2 sisi (uji Mann Whitney-Wilcoxon 2 arah) 
Pada tabel 2 ini, dipisahkan antara dividen naik dengan inisiasinya dan dividen turun dengan omisi dividennya. Hal ini dilakukan sebagai pengujian tambahan, dalam hal ini peneliti ingin melihat apakah kasuskasus ekstrem seperti inisiasi dividen juga responsible (Aharony \& Dotan, 1994) terhadap hasil yang ditunjukkan pada tabel 1. Pada tabel 2, pengolahan data diperoleh dengan menggunakan prosedur yang sama seperti apa yang dilakukan pada tabel 1 . Sebagai informasi awal perlu diketahui bahwa pada lampiran tes non parametrik periode 1992-1995, tidak satupun periode tahun atau secara keseluruhan terjadi hasil yang signikan. Pada periode 1992-1995 berada pada dimana Asymp. sign. sebesar 0,331. Ini berarti tidak satupun hasil dari periode tahun penelitian yang mengalami signifikan secara statistik.

Hasil yang diperoleh mengindikasikan bahwa rata-rata UEY

( $\overline{\mathbf{U E Y}}$ ) yang diperoleh juga mengindikasikan mendukung hasil bahwa tidak terdapat indikasi hubungan yang positif antara kasus ekstrem (inisiasi dan omisi) dari unexpected dividend terhadap peningkatan rata-rata UEY. Walaupun secara keseluruhan (1992-1995) output dari inisiasi dividen menghasilkan rata-rata persentase unexpected earnings yang meningkat yaitu sebesar 8,66\%, namun ternyata output dari omisi dividen bahkan juga menghasilkan rata-rata persentase unexpected earning yang meningkat yaitu sebesar 3,02\%, meskipun memang peningkatan UEY lebih besar ketika inisiasi dibanding omisi deviden. Dengan demikian, hasil juga mendukung kesimpulan sebelumnya, dimana meskipun dengan kasus ekstrem peningkatan/inisiasi (penurunan/omisi) dividen tidak selalu berpengaruh pada peningkatan (penurunan) rata-rata persentase unexpected earning yield ( $\overline{\boldsymbol{U E Y}}$ ) pada periode berikutnya. Dan dari hasil-hasil di atas, dapat peneliti ambil kesimpulan bahwa $H_{0}$ tidak dapat ditolak, atau hasil penelitian mengindikasikan menerima $\left(H_{0}\right)$

\section{Pengujian hipotesis kedua $\left(\mathrm{H}_{2}\right)$}

Tabel 3 menyajikan rangkuman hasil estimasi dari persamaan 2a, untuk tiap tahun periode penelitian serta secara keseluruhan (overall). Hasil mengindikasi bahwa dari grup dividen yang meningkat $\left(\Delta D^{+}\right)$, yang diwakili dengan koofisien $a_{1}$, kenaikan dividen memang menghasilkan unexpected earning yield yang positif yaitu pada periode penelitian tahun 1995 sebesar 0,0069, dan secara keseluruhan (overall) yaitu sebesar 0,0005. Namun untuk periode tahun 1992, 1993, dan 1994, justru peningkatan dividen mengakibatkan penerunan unexpected earning yield, yaitu sebesar 0,$0017 ;-0,0002$; dan $-0,0018$, sesuai dengan urutan periode tahun yang disebutkan sebelumnya. 
Hasil yang bercampur juga dapat kita lihat pada grup dividen yang menurun $(\Delta D)$, yang diwakili dengan koofisien $\mathrm{a}_{2}$, dimana penurunan dividen hanya menurunkan besarnya unexpected earning yield pada periode tahun 1993 yaitu sebesar -0,0170, namun untuk periode tahun yang lain 1992, 1994, 1995 dan 1992-1995 (overall), penurunan dividen justru meningkatkan unexpected earning yield yaitu sebesar 0,0104; 0,0164; 0,151; dan 0,0525, berdasarkan urutan periode tahun yang disebutkan sebelumnya.

Tabel. 3

Hasil Regresi Persamaan 2a.

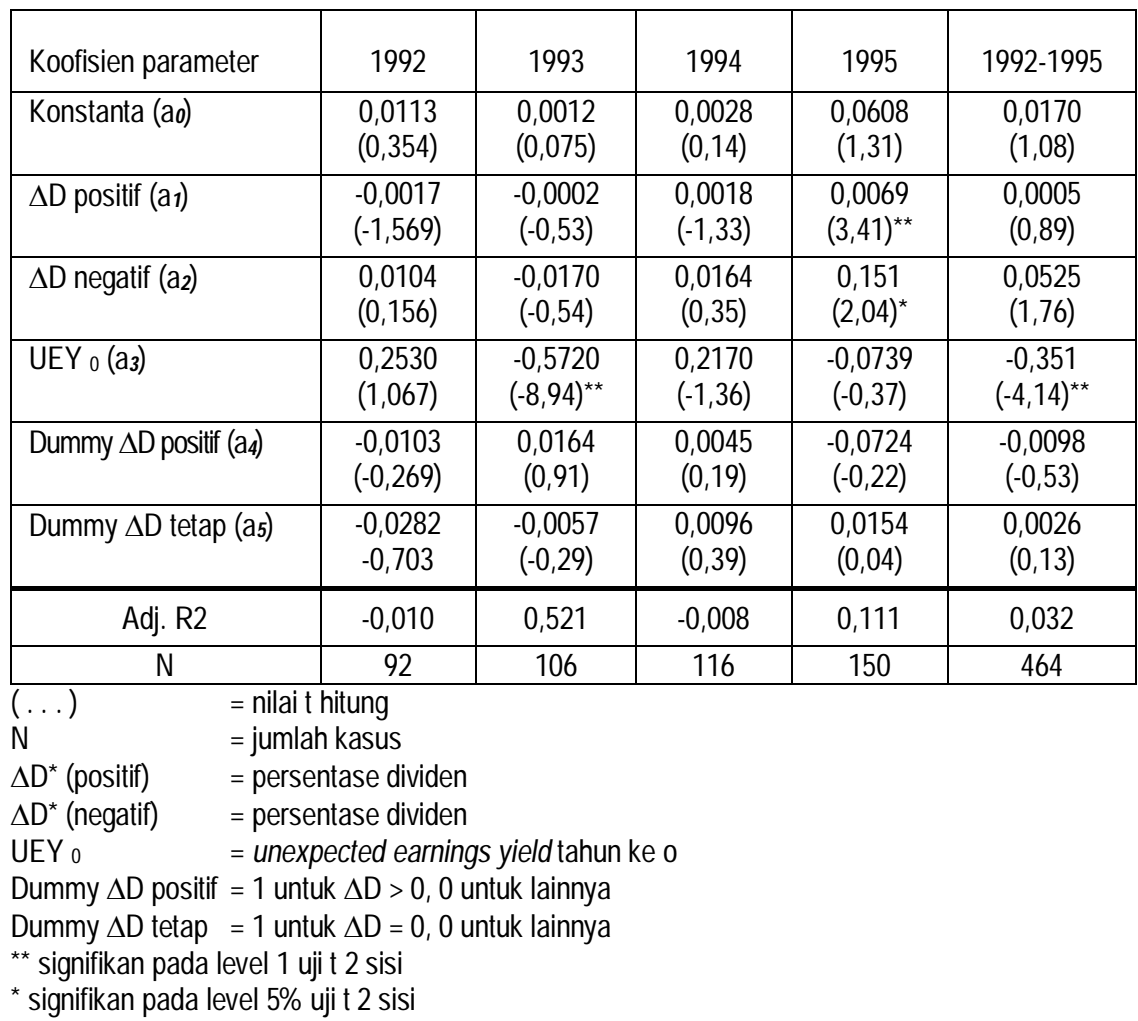

Untuk analisa lebih lanjut, dalam melihat hubungan antara perubahan dividen dengan future unexpected earnings, koofisien a0, a4 dan a5 harus diinterpretasikan sebagai berikut (Aharony \& Dotan, 1994); a0 mewakili intersep bagi grup dividen yang menurun; $(\mathrm{a} 0+\mathrm{a} 4)$ mewakili intersep bagi grup dividen yang meningkat; dan $(\mathrm{a} 0+\mathrm{a} 5)$ mewakili intersep bagi grup dividen yang tetap. Sebagaimana yang ditunjukkan pada tabel 3 , 
hasil estimasi dari a0, a4, dan a5 dalam tiap periode tahun penelitian secara statistik tidak signifikan (statistically unsignificant).

Secara keseluruhan (1992-1995), hasil menunjukkan bahwa intersep untuk grup dividen menurun (a0) adalah sebesar 0,0170, sementara untuk grup dividen meningkat $(\mathrm{a} 0+\mathrm{a} 4)$ intersepnya adalah sebesar -0,0072 dan intersep untuk grup dividen tetap (a0 + a5) adalah sebesar 0,0196. Dapat dilihat juga bahwa justru grup dividen yang tetap, lebih menghasilkan unexpected earning yield yang lebih besar, dibanding grup dividen menurun dan meningkat.

Hal tersebut dapat diartikan bahwa hasil penelitian ini pada akhirnya mengindikasikan penambahan bukti bahwa tidak ada kandungan informasi yang dibawa oleh pengumuman dividen terhadap keuntungan yang akan diperoleh perusahaan pada periode (tahun) setelah periode pengumuman dividen terjadi. Justru dari hasil estimasi dari persamaan $2 \mathrm{a}$ (pada tabel 3) diperoleh indikasi kesimpulan bahwa grup dividen yang tetap menghasilkan unexpected earning yield yang lebih besar (yaitu sebanyak 3 periode penelitian, 1994, 1995 dan 1992-1995).

Dari hasil regresi tersebut, hasil penelitian juga mengindikasikan bahwa perubahan (peningkatan/penurunan) dividen perusahaan justru lebih disebabkan oleh perubahan (peningkatan/penurunan) unexpected earning yield pada periode perubahan dividen terjadi (UEY 0). Hal ini dibuktikan dengan tingginya tingkat signifikansi statistiknya, berdasarkan uji uji t, pada periode secara keseluruhan (1992-1995), yaitu dengan signifikansi statistik sebesar 0,000 (signifikan pada level standar kepercayaan 1\% dan 5\%).

Untuk lebih menambah bukti dan keyakinan, peneliti merasa perlu melakukan uji statistik $\mathrm{F}$ yang dilakukan pada periode tahun peneliti secara keseluruhan. Untuk persamaan $2 \mathrm{a}$, koofisien nilai $\mathrm{F}$ hitung adalah sebesar 4,018 , sedangkan derajat bebas $(F: 5,458)$ diperoleh $F$ tabel sebesar 2,22, berarti nilai $\mathrm{F}$ hitung $>\mathrm{F}$ tabel, ini berarti $\mathrm{HO}$ tidak dapat diterima.

Perlu pula ditambahkan disini, bahwa rendahnya nilai t statistik yang dihasilkan pada tabel 2, tabel 3, dan tabel 4, mengindikasikan bahwa tidak cukup bukti untuk mengatakan bahwa dividen memiliki kandungan informasi terhadap future earning. Hasil $t$ statistik yang rendah juga dihasilkan oleh peneliti-peneliti yang dilakukan oleh Watts (1973), Gonedes (1978), dan Pennman (1983), seperti yang dikutip dari Benartzi (1999).

Akhirnya, hasil penelitian yang diperoleh oleh peneliti kali ini, berdasarkan data tahun penelitian 1992-1995, secara konsisten menghasilkan suatu indikasi kesimpulan yang sama dalam menemukan jawaban atas hipotesis pertama $\left(H_{1 a}\right.$ dan $\left.H_{1 b}\right)$ dan hipotesis kedua $\left(H_{2}\right)$, yaitu tidak dapat menolak $H_{0}$ atau menerima $H_{0}$ dengan interpretasi bahwa perubahan dividen tidak berpengaruh terhadap keuntungan perusahaan di waktu yang akan datang. 


\section{KESIMPULAN DAN SARAN}

\section{Kesimpulan}

Dari hasil penelitian yang telah dilakukan untuk data periode tahun 1992-1995 ini, maka peneliti mengambil beberapa kesimpulan sebagai berikut:

1. Berdasarkan hipotesis pertama, maka hasil penelitian mengindikasikan bahwa pengumuman perubahan dividen maupun kasus dividen yang tidak berubah (unexpected dividend change) untuk data tahun 19921995, tidak berpengaruh secara signifikan (statistically unsignificant) terhadap peningkatan (penurunan) keuntungan perusahaan (future unexpected earnings).

2. Berdasarkan hipotesis kedua, hasil penelitian juga menghasilkan keputusan yang tidak signifikan secara statistik (statistically unsignificant) mengindikasikan bahwa pengumuman dividen tidak memiliki kandungan informasi ke pasar (menolak hipotesis Information content of dividend).

3. Dari hasil penelitian juga diperoleh indikasi bahwa peningkatan (penurunan) dividen lebih disebabkan keuntungan perusahaan pada periode yang sama dengan dilakukannya pengumuman dividen, bukan menggambarkan peluang profitable perusahaan di waktu yang akan datang.

\section{Saran-saran}

Sebagai bagian akhir dari penelitian ini, maka peneliti mencoba memberikan beberapa masukan kepada pihak-pihak yang berkepentingan berdasarkan hasil penelitian yang telah dilakukan:

1. Para investor diharapkan lebih berhati-hati dalam menanggapi atau bereaksi terhadap pengumuman perubahan dividen yang dilakukan pihak manajemen perusahaan, karena pengumuman dividen tidak memiliki kandungan informasi mengenai keuntungan perusahaan di waktu yang akan datang.

2. Pihak manajemen perusahaan lebih baik menjaga kestabilan pembayaran dividennya, namun pihak manajemen bisa meningkatkan pembayaran dividennya sampai pihak manajemen sendiri benar-benar yakin akan peluang keuntungan perusahaan diwaktu yang akan datang. Diharapkan dengan kondisi tersebut pasar akan lebih atraktif dalam hal perputaran modal, karena investor tidak merasa tertipu akan perubahan dividen. 


\section{DAFTAR PUSTAKA}

Aharony, J., dan Dotan, A., "Reguler Dividend Announcements and Future Unexpected Earnings: An Empirical Analysist", The Financial Review, Vol. 29 No. 1, Februari 1994, hal. 125-151,

Amsary M. Ishak, "Pengaruh Pengumuman Dividen Terhadap Harga Saham Di Pasar Modal Indonesia", Tesis S-2, UGM Yogyakarta, 1993.

Asquith, P., dan D. W. Mullins, Jr., "The Impact of Initiating Dividend Payment on Shareholder's Wealth," Journal of Business 56, 1983, hal. 77-96,

Atmaja, L. S., "Manajemen Keuangan", Edisi revisi, Cetakan Pertama 1999, Penerbit Andi Yogyakarta,

Bajaj, M., dan Vijh, A. M., "Dividend Clienteless and The Information Content of Dividend Changes," Journal of Financial Economics 26, Agustus 1990, hal. 193-219.

Benartzi, S., Michaely, R., dan Thaler, R., "Do Changes in Dividends Signal The Future or The Past?", Journal of Finance, 1999,

Bhattacharya, S., "Imperfect Information, Dividend Policy, and The Bird In The Hand Fallacy", Bell Journal of Economic 10, 1979, hal. 259-270,

Brickley, J. A., "Shareholder Wealth, Information Signalling and the Specially Designated Dividend: An Empirical Study", Journal of Finance Economic, 12, Agustus 1983, hal. 187-209,

Charest, G., "Dividend Information, Stock Returns, and Market Efficiency II", Journal of Financial Economics 6, 1978, hal. 297-330,

Dennis dan Sarin., "The Information Content of Dividend Change: Cash Flow Signalling, Overinvestment, and Dividend Clientless", Journal of Financial and Quantitatif Analisyst, Desember 1994, hal. 567-587,

Foster, G., "Quarterly Accounting Data: Time Series Properties and Predictive Ability Results", The Accounting Review 52, Januari 1977, hal. 1-21,

Gonedes, N. J., Corporate Signalling, External Accounting, and Capital Market Equilibrium: Evidence on Dividens, Income, and Extraordinary Items", Journal of Accounting Research, 1978,

Healy, P. M., dan Palepu, K. G., "Earnings Information Conveued by Dividend Initiations and Omissions", Journal of Financial Economics 21, September 1988, hal. 149-175, 
Jogiyanto, H. M., "Teori Portofolio dan Analisa Investasi", Edisi Pertama, Cetakan Pertama, Desember 1998, hal. 318-328,

Lang, L. H. P., dan Lintzberger, "Dividend Announcements: Cash Flow Signalling vs Free Cash Flow Hipothesis", Journal of Financial Economics, September 1989, hal. 181-191,

Penmann S. H., "The Predictive Content of Earnings Forcase and Dividends", Journal of Finance 38, 1983,

Santoso, Singgih, "Aplikasi Excell Dalam Statistik Bisnis", Cetakan Kedua, PT Gramedia Jakarta, Agustus 1999,

Sudjoko, "Analisis Kandungan Informasi Dividen Dan Ketepatan Reaksi Pasar: Pengujian Terhadap Dividend Signalling Theory: Studi Empiris Di Bursa Efek Jakarta", Tesis S-2, UGM Yogyakarta, 1999,

Wansley, J., Sirman dkk., "Dividend Change Announcements Effect and Earnings Volatility and Timing", Journal of Financial Research, Spring 1991, hal. 37-49,

Watts, R. L., "The Information Content of Dividend", Journal of Business 46, April 1973, hal. 191-211,

Woolridge, J. R., "The Information Content of Dividend Change", Journal of Financial Research 5, Fall 1982, p. 237-247. 